MORBID SYMPTOMS 
Stanford Studies In Middle Eastern and Islamic Societies and Cultures 


\title{
Morbid Symptoms
}

\section{Relapse in the Arab Uprising}

\author{
Gilbert Achcar
}




\section{Stanford University Press Stanford, California}

C) 2016 by Gilbert Achcar. All rights reserved.

Published by Stanford University Press

No part of this book may be reproduced or transmitted in any form or by any means, electronic or mechanical, including photocopying and recording, or in any information storage or retrieval system without the prior written permission of Stanford University Press.

Printed in the United States of America on acid-free, archival-quality paper

Library of Congress Cataloging-in-Publication Data

Names: Achcar, Gilbert, author.

Title: Morbid symptoms : relapse in the Arab uprising / Gilbert Achcar.

Description: Stanford, California : Stanford University Press, 2016.

Includes bibliographical references and index.

Identifiers: LCCN 2016011912 (print) | LCCN 2016012450 (ebook) |

ISBN 9781503600300 (cloth : alk. paper) |

ISBN 9781503600317 (pbk. : alk. paper) | ISBN 9781503600478 (eBook)

Subjects: LCSH: Arab Spring, 2010- | Protest movements--Arab countries. |

Syria--History--Civil War, 2011- | Egypt--History--Protests, 2011- |

Syria--Politics and government--2000- | Egypt--Politics and government--21st century.

Classification: LCC JQ1850.A91 A335 2016 (print) | LCC JQ1850.A91 (ebook) |

DDC $909 / .097492708312--d c 23$

LC record available at http://lccn.loc.gov/2016011912

Cover design: Christian Fuenfhausen

Cover cartoon: Ali Ferzat 
The crisis consists precisely in the fact that the old is dying and the new cannot be born; in this interregnum a great variety of morbid symptoms appear.

Antonio Gramsci, Prison Notebooks (1930)

With this system I'll make my fortune quickly; then I will kill everybody and leave.

Alfred Jarry, King Ubu (1896) 
